\title{
Hematological and Biochemical Responses ofEndangered Caspian Brown Trout, Salmo Trutta Caspius during Acclimation to Seawater Salinity
}

\author{
Mazdak Pakzad Sorki ${ }^{1^{*}}$, Mehrdad Sarkheil ${ }^{2}$, Ahmad Rafieepour ${ }^{3}$ \\ 'Propagation Center, Breeding and Restocking Fish Shahid Rajai Sari, Iran \\ ${ }^{2}$ Faculty of Marine Science and Technology, University of Hormozgan, Bandar Abbas, Iran \\ ${ }^{3}$ Department of Fisheries, Faculty of Natural Resources, University of Jiroft, Kerman, Jiroft.
}

"Corresponding author: Mazdak Pakzad Sorki, Propagation Center, Breeding and Restocking Fish Shahid Rajai Sari, Iran, Tel: +98-76-33711000/11; E-mail: mazdakk.pakzad@gmail.com

Citation: Sorki MP, Sarkheil M, Rafieepour A (2017) Hematological and Biochemical Responses of Endangered Caspian Brown Trout, Salmo Trotta Caspius During Acclimation to Seawater Salinity. J Fish Aquac Dev, 2017: JFAD 111. DOI:10.29011/JFAD$111 / 100011$

Received Date: 05 June, 2017; Accepted Date: 12 June, 2017; Published Date: 20 June, 2017

\begin{abstract}
Smolts of Caspian brown trout were introduced to water with salinity of $12 \mathrm{~g} / 1$ to find hematological and biochemical responses in relation to sea-water acclimation. A total of $360 \mathrm{fish}(6.2 \pm 0.13 \mathrm{~g})$ were randomly distributed into 6 tanks in groups of 20 with three replicates (totally 12 tanks). Three groups were included as experimental treatments and one group allocated to control. In experimental treatment, fish were acclimated to water with $12 \mathrm{mg} / 1$ salinity for $48 \mathrm{~h}$. fish of control group were not acclimated to sea water salinity. After acclimation in sea water, the higher values of plasma cortisol and glucose were found in fish acclimated to sea water compared to control group $(P<0.05)$. There were no significant differences between experimental groups and control group in terms of plasma levels of potassium and sodium $(\mathrm{P}>0.05)$. Also, plasma protein levels were lower in fish acclimated to seawater compared to control $(\mathrm{P}<0.05)$. The values of $\mathrm{RBC}, \mathrm{WBC}$ and $\mathrm{Hb}$ increased significantly after sea water acclimation $(\mathrm{P}<0.05)$. Our results showed smolts of Caspian brown trout are able to regulated ions which may be in related to some changes in hematological parameters.
\end{abstract}

Keywords: Red blood cell, salinity, stress, Caspian brown trout

\section{Introduction}

Caspian brown trout is one of the most ecologically important fish species livingin Caspian Sea as an endangered fish because overfishing and loss of natural habitats in sea and related rivers[1-3]. Natural stocks of Caspian brown trout are preserved in many rivers in the parts of Iran. Thus, thousands of Caspian brown trout smolts are annually produced by government hatcheries and released to sea ranged to restock the decreasing populations [1-3]. Adaptation to sea water salinity is the most important stage for released smolts of Caspian brown since fish must be able to be adapting with increased salinity. Generally, an appropriate understanding on physiological bases of this adaptation may help to identify the biomarkers of osmoregulation in this species.Changes of hematological components are reported as parameters of fish health in relation to environment and nutritional conditions [4-7].

In Caspian brown trout, the mechanisms involved in osmoregulation are principally like other teleosts. These include changes in ability of gillin ion exchangedue to the changes in cortisol levels, chloride cells $[8,9]$. However, little information is available regarding hematological parameters such as the number of red blood cells, white blood cells, hemoglobin, proteins and etc. Therefore, this study was conducted to evaluate the effects of sea water acclimation on hematological and biochemical components of Caspian brown trout, with two major objectives: (1) provide data on plasma biochemical parameters, and (2) to assay how plasma biochemistry is alerted following sea water acclimation.

\section{Materials and Methods}

A total of 360 fish $(6.2 \pm 0.13 \mathrm{~g})$ were prepared from Ka- 
Citation: Sorki MP, Sarkheil M, Rafieepour A (2017) Hematological and Biochemical Responses of Endangered Caspian Brown Trout, Salmo Trotta Caspius During Acclimation to Seawater Salinity. J Fish Aquac Dev, 2017: JFAD 111.

lardasht Salmonids Reproduction Centre (KSRC), Iran. Then, fish randomly distributed into 12 tanks in groups of 20 with three replicates (totally 12 tanks). Three groups were considered as experimental treatments and one group considered as control. After 3 days' adaptation to tank condition, in experimental treatment, fish were exposed to water with $12 \mathrm{mg} / \mathrm{l}$ salinity for $48 \mathrm{~h}$. fish of control group were not introduced to salinity acclimation. Fish were not fed throughout the experimental period $(48 \mathrm{~h})$. The water salinity $(12 \mathrm{mg} / \mathrm{l})$ was provided by addition of sea salt. The aeration

of tanks was carried out to maintain the levels of dissolved oxygen at $7.1 \pm 0.13 \mathrm{mg} / \mathrm{L}^{-1}$, and also water temperature and $\mathrm{pH}$ during the experiment were maintained at $17.1 \pm 0.11^{\circ} \mathrm{C}$ and $7.5 \pm$ 0.12 , respectively. Water was exchanged in order to prevent ammonia toxicity and other wastes in the tanks every $12 \mathrm{~h}$.

Fish Sampling and Analytical Methods: The blood samples were collected from the caudal vein with syringes in two steps: (1) before acclimation to SW (2) $48 \mathrm{~h}$ after acclimation to SW. Before blood sampling fish were anesthetized with MS222 (200 $\mathrm{mg} \mathrm{L}^{-1}$ for 5-10 min).Then, an aliquot of blood samples was used for determination of RBCs, WBCs and Hb.The reminders were centrifuged and plasma samples usedto assay cortisol, glucose, potassium $\left(\mathrm{K}^{+}\right)$, sodium $\left(\mathrm{Na}^{+}\right)$and total protein. All biochemical and hematological components were assayed according to [10]. In this regard, $\mathrm{RBC}$ counting was performed by using hemocytometers. The concentration of $\mathrm{Hb}$ was measured using by spectrometer according to cyanmethemoglobin method at wavelength of $550 \mathrm{~nm}$. Plasma cortisol was assayed with the method of Radioimmunoassay. Plasma glucose was assayed with assayed kit. Plasma $\mathrm{K}^{+}$and $\mathrm{Na}^{+}$values were measured using a Flamephotometer.

Data Analysis: The data of the present study was analyzed by using SPSS software. The data normality was determined with Kolmogorov-Smirnov test before analysis of variance. Then, oneway analysis of variance(ANOVA) was employed to compare the means. After determining the F-values, the Tukey test was used to determine which groupswere different.

\section{Results}

The higher values of plasma cortisol (Fig 3) and glucose (Fig 2 ) were observed in fish acclimated to sea water compared to control group after acclimation to sea water $(\mathrm{P}<0.05)$. There were no significant differences between experimental groups and control group in terms of plasma levels of potassium (Fig 7) and sodium (Fig 8) ( $\mathrm{P}>0.05)$. Also, plasma protein levels were lower in fish acclimated to sea water compared to control (Fig 1, $\mathrm{P}<0.05$ ). The values of RBC (Fig 4), WBC (Fig 5) and Hb (Fig 6) increased significantly after sea water acclomation $(\mathrm{P}<0.05)$.

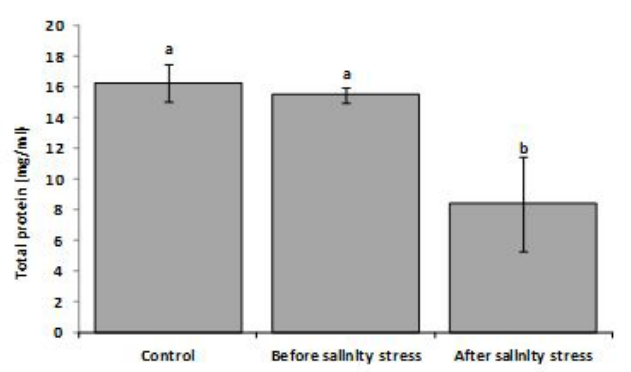

Figure 1: Changes of total protein in the serum of Caspian brown trout smolts after $48 \mathrm{~h}$ acclimation in sea water.

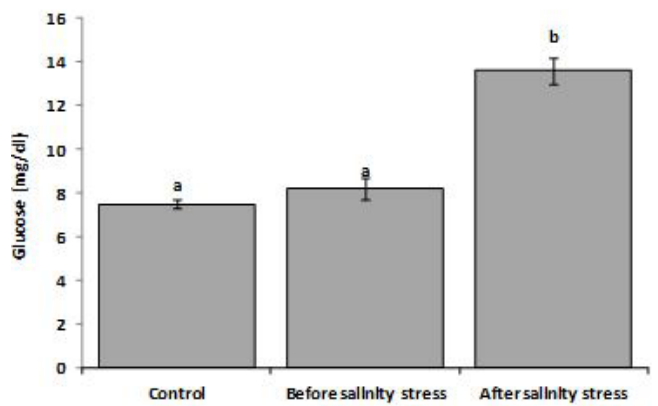

Figure 2: Changes of glucose in the serum of Caspian brown trout smolts after $48 \mathrm{~h}$ acclimation in sea water.

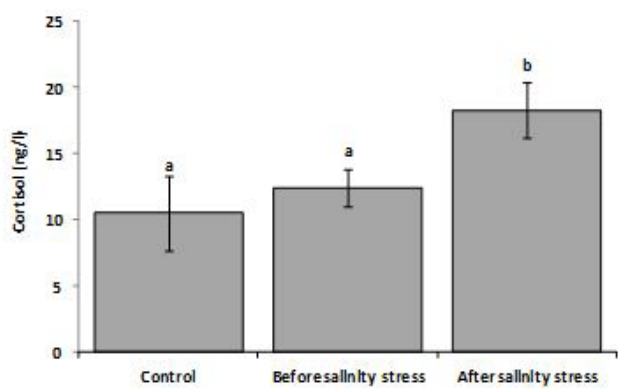

Figure 3: Changes of cortisol in the serum of Caspian brown trout smolts after $48 \mathrm{~h}$ acclimation in sea water.

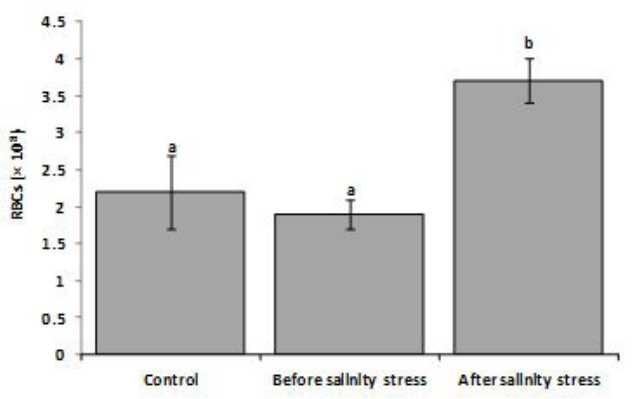

Figure 4: Changes of RBCs in the serum of Caspian brown trout smolts after $48 \mathrm{~h}$ acclimation in sea water. 


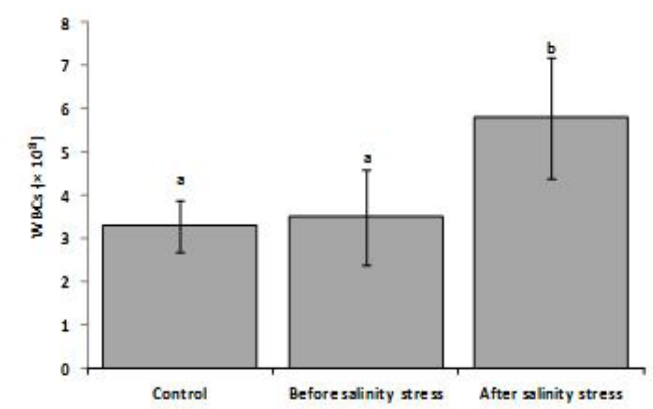

Figure 5: Changes of WBCs in the serum of Caspian brown trout smolts after $48 \mathrm{~h}$ acclimation in sea water.

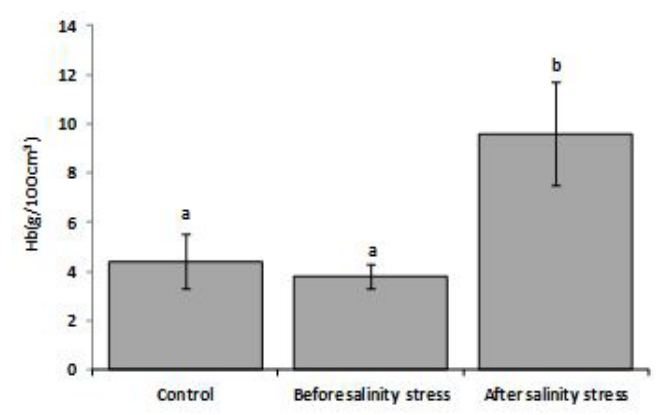

Figure 6: Changes of $\mathrm{Hb}$ in the serum of Caspian brown trout smolts after $48 \mathrm{~h}$ acclimation in sea water.

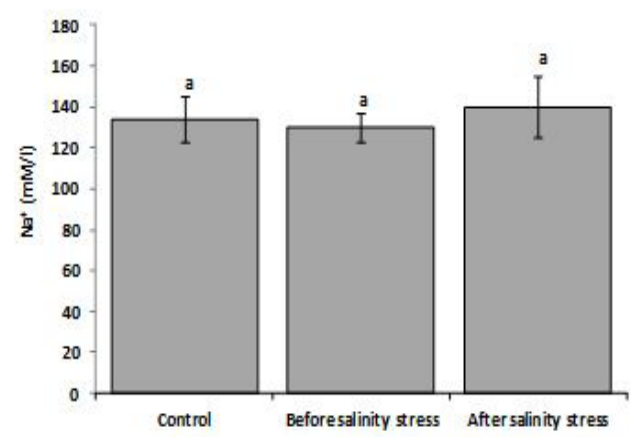

Figure 7: Changes of $\mathrm{Na}^{+}$in the serum of Caspian brown trout smolts after $48 \mathrm{~h}$ acclimation in sea water.

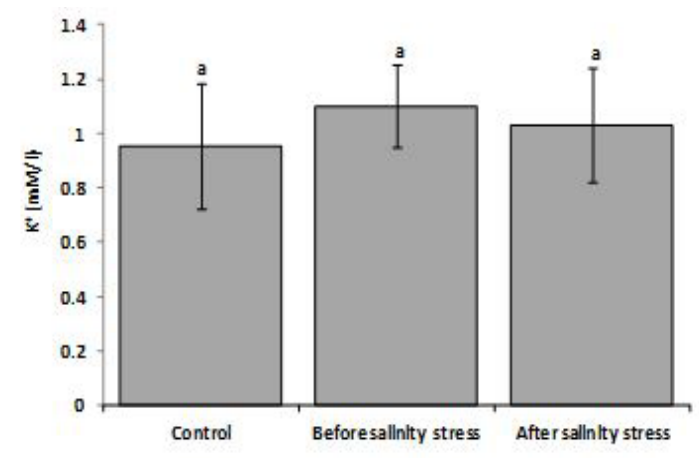

Figure 8: Changes of $\mathrm{K}^{+}$in the serum of Caspian brown trout smolts after $48 \mathrm{~h}$ acclimation in sea water.

\section{Discussion}

In the present study, plasma cortisol and glucose were higher in fish acclimated to sea water salinity compared to those in control group. The role of cortisol on osmoregulatory components has been well identified in teleosts [11]. Also, it is well known that stress caused hormonal responses, such as the elevation ofplasma cortisol and catecholamines, which this in return these hormones regulate the osmoregulation ability of fish in relation to hypotonic environments such sea water [12]. In general, cortisolenhances the tolerance of fish to high osmotic pressure through its effects on the permeability of cell membrane, increasing glycogenolysis in liver and further elevations in plasma glucose. Also, this hormone increasesthe activity of $\mathrm{Na}^{+} / \mathrm{K}^{+}$-ATPase and the number and size of chloride cells [11]. Thus, the elevation of cortisol and glucose in our study may be in association with the key role of cortisol in acclimation to sea-water in Caspian brown trout smolts.

Cortisol provides glucose for energetic costs of osmoregulation in sea water $[13,14]$. During osmotic acclimation of euryhaline fish species, the energy demand is usually provided by means metabolically glycogen breaking by cortisol action sudden increases in glucose [10]. In a previous report on Persian sturgeon fingerlings, the plasma cortisol levels increased clearly after $24 \mathrm{~h}$ acclimation to sea water, probably acknowledging the important role of this corticosteroid in promoting the liver glycogenolysis, subsequent releasing glucose into the blood and thus preparing the energy for hyperosmotic pressure.

In our study, there were no significant differences between experimental groups and control group in terms of plasma levels of potassium and sodium, indicating the high ability of smolts to regulate plasma ionic levels during $48 \mathrm{~h}$ acclimation to sea water. The lower plasma values of proteins in fish acclimated to sea water compared to those in control group may be due to the utilization of plasma proteins as energy sources for osmoregulation as reported by [15]. Proteins are modulated towards production of energy when glucose and lipids are not so enough for providing the energetic costs of osmoregulation [16]. In the present study, plasma levels of $\mathrm{RBC}$ and $\mathrm{Hb}$ increased significantly after acclimation to sea water. This result may be due to decreases in the water content of blood which this decrease in water returns to the effects of hyperosmotic [14]. Lose of water results increases in the concentrations of blood-cell components.

\section{Compliance with Ethical Standards}

\section{Ethical Approval}

All experiments were conducted under a protocol for the care and use of animals approved by the committee of ethics of the faculty of sciences of the University of Tehran (357; 8 November 2000). 
Citation: Sorki MP, Sarkheil M, Rafieepour A (2017) Hematological and Biochemical Responses of Endangered Caspian Brown Trout, Salmo Trotta Caspius During Acclimation to Seawater Salinity. J Fish Aquac Dev, 2017: JFAD 111.

\section{References}

1. Kiabi BH, Abdoli A, Naderi M (1999) Status of fish fauna in the south Caspian basin of Iran. Zoology in the Middle East 18: 57-65.

2. Hajirezaee S, Mojazi Amiri, Mirvaghefi AR, Sheikh Ahmadi A (201 0a) Evaluation of semen quality of endangered Caspian brown trout (Salmo truttacaspius) in different times of spermiation during a spawning season. Czech J. Anim. Sci 55: 445-455.

3. Hajirezaee S, MojaziAmiri B, Mirvaghefi AR (201 0b) Changes in sperm production, sperm motility, and composition of seminal fluid in Caspian brown trout, Salmo truttacaspius, over the course of a spawning season. J. App. Aquacult. 22: 157-170.

4. Garcia-Navarro CEK (1994) Hematologia dos animaisdomésticos. In: Garcia-Navarro CEK, Pachaly JR (eds) Manual deHematologia veterinaria. Primeiraediçao, Sao Paulo, Varela11: 119.

5. Cataldi E, Marco PD, MandichA, Cataudella S(1998)Serum parameters of Adriatic sturgeon Acipensernaccarii (Pisces: Acipenseriformes). Effects of temperature and stress. Comp BiochemPhysiol A 121: 351-354.

6. Serpunin GG, Likhatchyova OA (1998) Use of the ichthyohaematological studies in ecological monitoring of the reservoirs. Acta Vet Brno 67:339-345.

7. Ranzani-Paiva MJT, Salles FA, Eiras JC, Ishikawa CM, Alexandrino AC (1999) Analisehematologica de curimbata (Prochilodusscrofa), pacu (Piractusmesopotamicus)tambaqui (Colossomamacropomum) das estaçoes de piscicultura do instituto de pesca. BollnstPesca 25:77-83.
8. Hoar WS (1988) The physiology of smolting salmonids. Fish Physiol XIB275-343.

9. Evans DH (1993) Osmotic and ionic regulation. In: The Physiology of Fishes. Evans DH, ed. Boca Raton, FL315-343.

10. Shahkar E, Kim DJ, Mohseni M, Yun H, Bai SC (2015) Effects of salinity changes on hematological responses in juvenile ship sturgeon Acipensernudiventris. Fish AquatSci 18: 45-50.

11. McCormick SD (2001) Endocrine control of osmoregulation in teleost fish. Am. Zool 41: 781-794.

12. Pickering AD, Pottinger TG (1995) Biochemical effects of stress. In: Hochachka PW and Mommsen TP, Eds. BiochemMoleculBiol Fish 5: 349-379.

13. Krumschnabel G, Lackner $R$ (1993) Stress responses in rainbow trout Oncorhynchus mykisselevens. Comp Biochem Physiol 104: 777-784.

14. Plaut I (1998) Comparison of salinity tolerance and osmoregulation in two closely related species of blennies from different habitats. Fish PhysiolBiochem 19: 181-188.

15. Huang $X$, Zhang L, Zhuang P, Zhang T, Zhao F, Feng G, et al.(2006) Hematological parameters of Amur sturgeon, Acipenserschrencki, during different salinity domestication. Mar Fish 28: 177-184.

16. Lin $H$ (1999) The physiology of fishes. Guangdong higher education press, Guangzhou China. 